Article

\title{
"The No to Nothing, and the Nothing to Know": Immanent Transcendence as Eschatological Mystery
}

\section{B. Keith Putt}

Philosophy Department, Samford University, 800 Lakeshore Drive, Birmingham, AL 35229, USA; bkputt@samford.edu

Academic Editor: Justin Sands

Received: 13 February 2017; Accepted: 5 April 2017; Published: 11 April 2017

\begin{abstract}
At an annual American Academy of Religion conference thirty years ago, Robert Scharlemann presented a paper in which he compared and contrasted Barth and Tillich with reference to how they named God in their respective theologies. He suggested that the former labeled God the "no to nothing," while the latter symbolized God as the "nothing to know"-appellations out of which he formed his presentation title "The No to Nothing and the Nothing to Know: Barth and Tillich and the Possibility of Theological Science." I have purloined Scharlemann's title for my own essay, with the intent not only to maintain its theological implications but also to use it as a rubric for prosecuting the putative relationships that obtain among anticipation, nihilism, transcendence, mystery, and eschatology. If there are various species of transcendence, and if one can use and not merely mention the word "mystery" in some constative manner, then how may one speak of the actuality and potentiality of meaning? Is there a futurity to existential significance that empowers a life-affirming hope, which, in turn, embraces the inescapability of the "nothing" without plunging, or leaping, into the abyss of nihilism - the "no to nothing?" Alternatively, may one genuinely anticipate eschatological aspirations while remaining open to the enigma of the unprogrammable aleatoric "to come" - the "nothing to know?" Furthermore, how might one name "God" under either of these circumstances, even were one not to hold to any type of confessional theological ontology? Using John Caputo's radical theology of the insistence of "God" as my Virgil (or Beatrice, which ever applies!) to guide us through the various paths one might take towards a genuine hope, I propose to investigate the plurivocity of discourses on meaning by inter-relating Caputo's "nihilism of grace" with several supplementary works, including Ray Hart's God Being Nothing, Amie Thomasson's Fiction and Metaphysics, Stuart Kaufmann's Humanity in a Creative Universe, Catherine Keller's Cloud of the Impossible, and Richard Kearney's Anatheism. Additionally, I will also consult aesthetic vocabularies that address the issue, specifically the poetry of Robert Browning, Dan Fogelberg, and Wallace Stevens, along with the Abstract Expressionist work of Mark Rothko. I will conclude the essay by suggesting that although one may expound on the desire for existential meaning through diverse discourses, if there is genuinely any realization of that meaning, it will occur regardless of how it is articulated. That is to say, the creative and transformative function of any transcendent meaning may work ex opere operato in a manner similar to Shakespeare's rose that does not depend on one exclusive naming.
\end{abstract}

Keywords: Caputo; Rothko; Derrida; Keller; deconstruction; nihilism; anatheism; messianic; theopoetics; mysticism

Ah, but a man's reach should exceed his grasp,

Or what's a heaven for? (Browning 1974) 
There is no Eden

Or heavenly gates

That you're gonna

Make it to one day

All of the answers

You seek can be found

In dreams that

You dream all along the way. (Fogelberg 1974)

For the listener, who listens in the snow,

And, nothing himself, beholds

Nothing that is not there and the nothing that is. (Stevens 1982b)

"In Anticipation: Transcendence and Eschatology in Contemporary Contexts" serves as a fascinating and provocative title for this special issue of Religions. It appeals to me not only for what it states in its overt textuality-the four relatively apparent concepts clearly articulated or implied-but also for what lies written covertly between the lines-the two important concepts that seem to be "said" through the silence of an "un-said." Three of the overt concepts are quite obvious: anticipation, transcendence, and eschatology. These three ideas share semantic affiliations that manifest a logical movement from the first through the second to the third. "Anticipation" names an attitude of expectation, of awaiting, or of hoping for that which remains to be realized or made present. One always anticipates the future, specifically the future arrival of something yet to come. The object of anticipation, therefore, never exists in the here and now. Although it may well be imminent in its coming, it can never be immanent in its availability. As a result, the anticipated must always remain in some manner transcendent as a something beyond, a something that, in its alterity, beckons towards another reality. Of course, that reality may be homogeneous in its alterity, in some way a "more of the same"; yet, it may also be heterogeneous in that it signals something other and different, a "beyond" that escapes the confines of the status quo. Regardless of how one may interpret the transcendent, however, it, nevertheless, gestures toward something fulfilling, a telos or purpose that could possibly give new meaning to one's existence. In other words, the "transcendent" may imply an "eschatology," a concern for the "last things" as what can functionally add a sense of completion of, or a narrative logic to, the multiple episodes of one's life. Consequently, one may easily trace the itinerary of meaning that interconnects the overt concepts, leading to the affirmation that we constantly anticipate that which lies beyond the here and now and promises the potentiality of an existentially meaningful purpose to life.

Yet, I contend that one may also successfully argue for a fourth overt concept in the title, one not directly asserted but conspicuously intended, that is, the concept of the religio-theological. A simple genealogy of the word "eschatology" reveals that its pedigree includes the decidedly religious and theological, since it typically addresses the doctrine of the "end of days" or of the divine conclusion to time and history. Likewise, the word "transcendence" carries its own religious and theological pedigree, since it regularly occurs in discourses dedicated to reflecting on the possible existence and the specific character of God. Given that anticipation may also betray a religious or theological nuance through its synonymity with hope, the discursive "deck" of the title seems to be stacked in favor of prosecuting the associations among the three major terms within the context of religious language.

Moreover, the fourth overt concept suggests compelling connotations for how to relate anticipation, transcendence, and eschatology to humanity's conatus essendi for meaning and purpose. Religion often relies on theology to flesh out the anticipatory deliverance of a plastic existence, which can be molded and transfigured into something ennobling and liberating. That is to say, what one anticipates or hopes for is an intervention from God, who offers release and relief through the divine restoration of order, the cleansing affirmation of forgiveness, and the rebalancing equality of justice. Theological systems of thought reflect on these sacred events of meaning by reflecting on God's 
transcendent power, on the fact that God is a Wholly Other, one who surpasses mundane categories of existence and can, therefore, offer the novelty of a new creation. Divine transcendence insures us against the myopia of a reductionistic acceptance of existence as a closed system of scientific materialism, or, at least, offers a poetic vocabulary for naming a beneficial dynamic that might not reference another reality but never capitulates stoically to a future that differs in no way from the past. That is to say that talk (logos) about God (theos) is talk about a meaningful mutability that escapes a Nietzschean eternal return of the same and embraces the Kierkegaardian contingencies of a repetition forward (Kierkegaard 1983, p. 149).

Naturally, the perennial question of transcendence remains whether one can construe it with either a maximum or a minimum metaphysics that allows for "God" to name an entity of some sort or whether transcendence can only be articulated through theological idioms that remain firmly attached to the reality comprehended by physics. Either way, however, the issue of transcendence inexorably leads to the idea of eschatology, since regardless of the substance afforded to theories of transcendence, the structure remains one of acknowledging a teleological efficacy at work in anticipating some end or purpose to existence. Is there a point to it all? Can one genuinely speak of a raison d'être, not so much in the sense of Leibniz's principle of sufficient reason but in the sense that life is not chaotically and aimlessly meandering through the flux but has a purpose, a goal, or a final cause that lends a certain narrative logic to the petits récits of lived experience?

Precisely at this point, one must contemplate the two covert concepts that haunt the issues inherent in the issue title, those ambiguous spirits that possess the body of the text and evoke a certain spectral dis-ease. One simply cannot avoid feeling the inevitable influences of the idea of mystery and the idea of nothingness. When pondering the substance of anticipation, of transcendence, or of eschatology, we cannot shake the realization that we may not actually know what it is that we expect, or what exactly characterizes the alterity and difference of that which lies "beyond," or whether any genuine purpose or definitive denouement will truly develop to offer a "sense of an ending" to our lives (Kermode 1967). Furthermore, even if we convince ourselves that we know the content of our religious and theological projections, we do not know if and when they will finally "come." That is to say, we find ourselves inextricably wrestling with uncertainty, with a constant risk that our hopes and desires will never be fulfilled. Nor do we have any final knowledge of the temporality of all of this, of when to expect a transcendent redemption or transformation that will satisfy our lust for meaning. We must, instead, contend with a systemic non-knowing, with a necessitated mystery that never transmutes into a problem that can be solved but that always remains "transcendent," lying just beyond our comprehension and our control. Such mystery frustrates us while simultaneously invigorating us. We chafe against the limits of and to our reason and our capacities; yet, we are lured forward toward transcendence and purpose by that very same anticipatory dynamic of the enigmatic. The mystery, then, in its attracting enticement ensures that our aspirations remain active.

Still, the mystery consistently reminds us that all of our love for anticipation, all of our faith in something transcendent, and all of our hope for a purpose to be realized may only be so much smoke and mirrors, intimations of nothing, a nothingness that offers no referentiality of any sort. All of our discourse about future meaning may not only be imaginative, that is, poetic expressions that symbolize the plausibility of stepping beyond the reduction of the same, but may also be merely imaginary, a superstitious naiveté that believes in empty and vain non-realities. Indeed, the nihilist may well be correct. There may be nothing that establishes truth, virtue, or meaning. The future may not be any different from the past or the present, leaving us with the promise of nothing transformative, nothing restorative, and nothing assuasive. That presumptive nihil may well annihilate any primary affirmation or originary admission of historical corrigibility. Such a "death of God" or atheistic perspective disrupts the inherent confidence that one typically expects from anticipation, transcendence, and eschatology, leaving, at best, only the redemptive possibility of a Stoic consent to the lethality of a final emptiness, since there is no God to save us. 
All of the above comes to various expressions in the epigraphs that begin this essay. The general tenor of the interplay among anticipation, transcendence, and eschatology is captured succinctly in Robert Browning's famous claim that human beings should never acquiesce to a life in which striving for, or trusting in, the realization of something new fails to encourage an existential commitment "to strive, to seek, to find, and not to yield," as Alfred, Lord Tennyson, Browning's fellow Victorian poet, so beautifully declares it (Lord Tennyson 1974). To be sure, meaningfulness does so often depend on our dedication to reaching for that which exceeds our grasp, our acknowledging that anticipation is a grasping beforehand of that which we can never comprehensively comprehend. Either the transcendence of what we seek leads us to another world, to something beyond and heterological, or we only await an immanent transcendence, a promise that roots us firmly in the possibilities of this existence. Either way, Browning's poetic prescription of optimism encourages us not to go gentle into any good night of nihilism.

Dan Fogelberg also takes the view that we should hold tenaciously to the possibility that some transcendent meaning may be acquired within the immanence of life itself. He contends that there is no eschatological reality other than the dreams that we imagine throughout our striving. All of our answers may be discovered oneirically, with such imaginative revelations being simply "part of the plan." Yet, Fogelberg goes so far in the chorus of his lyric to encourage his listener to "Await your arrival/With simple survival/And one day we'll all understand." But, will we? Indeed? Are we guaranteed to confirm the answers that we seek to our queries about meaning and resolution? Perhaps. Perhaps not. Perhaps there always remains a "perhaps," a non-knowing that can never be negated, an agnosticism and mystery that evoke some sort of faith as a necessary corollary to hope. Such a systemic non-knowing of what might draw us into an eschatological incitement toward hope may well be what lies behind Wallace Stevens' cryptic image of the silent snowman, listening to and observing its wintry context. It is itself a "nothing" that perceives a two-fold nothingness. First, he perceives nothing that is not there, that is, only the empirical reality of material phenomena, the world as it is; second, he also perceives the nothing that is "there," a non-being that suggests mutability and the plausibility of a transformed existence, a poetic mutation effected by the imagination, the creative dreaming or visionary reaching that produces a dissatisfaction with the status quo. For Stevens, the nothing that is there is a nothing that one encounters only through the creative transformations of poetry. Yet, poetry never offers absolute knowledge, which means the risk of non-knowing cannot be resolved. Consequently, Stevens also poetically expresses the tension between mystery and nothing-ness.

\section{1. "No-ing" and Knowing Nothing}

The enigma of the nihil, the nothing that seems to haunt any explanation of anticipation, transcendence, and eschatology remains ambiguous. It may denote the inevitability of nihilism, the realization that there is nothing to grasp beforehand, nothing beyond that seduces us into hope, and nothing that presents itself as an end or goal that could grant life a design and direction. On the other hand, it may comport with mystery and index the salvific nothingness of our finitude, the limitations of our intellect with reference to abbreviating hope and meaning into conceptual idols that we can manipulate and control. This nothingness of humility may well be a significant component of the engine that drives our yearning after purpose and fulfillment. Indeed, were we to return to the theological implications of our discussion, then nothingness might well serve as an apophatic affirmation that we cannot genuinely know or speak about God and that an implicit but redemptive skepticism always accompanies our desires to anticipate and discern an eschatologically meaningful transcendent purpose. The above skepticism reminds us that prosecuting the issue of whether one may genuinely speak of a transcendent meaning or not entails a plurivocity of hermeneutical perspectives. These perspectives seek to explain a basis for trusting in the aspiration that one may find a "why" to existence, without exhausting or decisively confirming that aspiration. In other words, there are multiple discourses, both positive and negative, that seek to discover the "truth" about an alleged meaningful ontological raison d'être. 
In seeking a rubric for amplifying the implications that emerge from the tensive confederation among anticipation, transcendence, eschatology, mystery, and nihilism, I find myself fascinated by a rather creative chiastic formula used by Robert Scharlemann over three decades ago. At the annual conference of the American Academy of Religion in 1986, Scharlemann presented a paper in which he compares and contrasts Karl Barth and Paul Tillich with reference to how they name God in their respective theologies. He suggests that the former labels God the "no to nothing," while the latter symbolizes God as the "nothing to know" - appellations out of which he forms his presentation title "The No to Nothing and the Nothing to Know: Barth and Tillich and the Possibility of Theological Science" (Scharlemann 1989, p. 110). He insists that Barth's theology focuses on the name of God as the denomination of "the eternal no to the meaning of the word nothing" and that Tillich's theology emphasizes the symbol of God as the "symbol whose reality contains the nothing that we know in knowing the negation of nothing that is God" (Scharlemann 1989, p. 112). For both theorists, the provocative exigency of theology concerns how to account for the appearance of the word "God" in human language and "how, in a nihilistic age, is one to answer for that word in the tales and judgments connected with it" (Scharlemann 1989, p. 111).

Scharlemann contends that both theologians would certify that theology is impossible, given that human beings, as non-Gods, can never speak about God as God speaks about Godself; however, considering that human beings can also never avoid inquiring into theories about the meaning of cosmic beginnings and endings, even if such inquiries never lead to definitive answers, one must accede to the necessity of theology (Scharlemann 1989, pp. 116-17). For Scharlemann, such an admission leads conclusively to a contemplation on transcendence. Questions of commencements and culminations typically initiate questions that attempt to connect the divine with the cosmos. Doing so invigorates a theology that recognizes that "the world and everything in it can be read as a sign of another than itself and...that that other is understood as the meaning of the name "God'" (Scharlemann 1989, pp. 109-10).

Quite obviously and shamelessly, I have purloined Scharlemann's title for this essay, with the intent not only to maintain its theological implications but also to use it as a formulary for prosecuting the putative relationships that obtain among anticipation, transcendence, eschatology, mystery, and nihilism. If there are various species of transcendence, and if one can use and not merely mention the word "mystery" in some constative manner, then how may one speak of the actuality and potentiality of meaning? Is there a futurity to existential significance that empowers a life-affirming hope, which, in turn, embraces the inescapability of the "nothing" without plunging, or leaping, into the abyss of nihilism - the "no to nothing?" Alternatively, may one genuinely anticipate eschatological aspirations while remaining open to the enigma of the unprogrammable aleatoric "to come" - the "nothing to know?" Furthermore, how might one name "God" under either of these circumstances, even were one not to hold to any type of confessional theological ontology?

Traditionally, the above questions precipitate out of the tension between theism and atheism; however, now in the context of certain approaches to radical theology, that old polarity has lost some of its cachet. Yet, it may continue to maintain its significant connotations. Regardless of acceptable nomenclature, one sustains an abiding interest in whether the avoidance of nihilism demands an affirmation of a transcendent deity and of a hetero-ontic eschatological reality. In other words, can the denial of an entitative God ensure the denial of an eventual nihilism? Alternatively, if one decides against the metaphysical theology of a transcendent deity, is one compelled to reject mystery and embrace nihilism, thereby allowing only for anticipation to be a homogeneous expectation, transcendence to be merely an epistemological vector toward some predictable future, and eschatology to imply nothing more than the final reiteration of the status quo? In other words, can one interpret the "nothing to know" as something other than a divine entity, even, perhaps, by continuing to use the nomenclature of theology, and yet also develop a cogent argument that inculcates anticipation, transcendence, and eschatology in such a manner that a resounding "no to nothing" may be proclaimed and nihilism either rejected or redeemed? How many ways may one pursue existential meaning, with or without God, while simultaneously continuing to use a theological or religious glossary? 
In order to investigate various answers to the above questions and elaborate on the twofold rubric of the "no to nothing" and the "nothing to know," I have chosen to appropriate John D. Caputo's contemporary radical theology of the weakness of God. Why choose Caputo as the context for my investigation? Well, because, for decades, he has been overtly exploring the conjunctions among anticipation, transcendence, and eschatology, specifically as they relate to philosophy of religion and the-ology. Both his radical hermeneutics and his radical theology attempt to move past maximum meta-physical theories of a hetero-ontological foundation for existential purpose and also strong theologies of a hyperousiological deity that intervenes in reality. In doing so, however, his thought never falters in its emphases on mystery and meaning, emphases that insist that the word "God" continues to function as an important idiom for interpreting both the religio-ethical aspects of human existence and also for arguing against a hard nihilism that reduces reality to nothing more than a "new atheistic" scientism or a Feuerbachian humanism. His "systematic" treatment of the insistence of God allows for various supplements to be grafted into his structure, thereby allowing us to conclude that our titular topics may go under different names in a manner analogous to Caputo's claims concerning the substitutability of the name "God" (Caputo 2006, pp. 2-7). Subsequently, supplementing Caputo with diverse hermeneutical models of purpose and creativity may lead us to the conviction that the "no" to nothing and the "nothing" to know may well be like Shakespeare's rose. No matter what discourse one may employ in order to "name" the substance and process of anticipating a transcendent meaning yet to come, the existential functions of those discourses remain compatible. That is, indeed, my primary thesis: I propose that beyond the significant issue of "truth" that might rightly discriminate among the various theories of meaning, there lies a pragmatic pertinence, inherent within every idiom, of a successful acquisition of meaningful purpose, an expediency that flourishes across all interpretations.

\section{The Lure of Messianic Aspirations}

"Anticipation" in Caputo's radical theology goes under various synonyms: "hope," the "to-come," and the "messianic." His Derridean biases lead him inevitably to focus on what exceeds and, therefore, disrupts the hegemony of any status quo, any "metaphysics of presence" that purports to close the openness of existence and language with an absolute, definite, or exhaustively identifiable meaning, certainty, or truth. As a result, Caputo avoids playing sycophant to the prosaic possible and prefers, instead, to celebrate the poetic impossible. The "impossible" suggests that which cannot be predicted or programmed by human ingenuity, a something "to come" that can only be awaited and never adumbrated, a je ne sais quoi that leaves open the mystery as to what it may be and when it may be (Caputo 1997b, pp. 113, 133; Caputo 2006, p. 97). As such, the impossible is a certain extrapolation of Derrida's différance, the neologism that not only inculcates difference into every semiotic expression but also incorporates the notion of deferral, the idea that precise meaning is deferred until a later time, lies always in the future, the "l'avenir," which means, etymologically, the "to come" (Caputo and Vattimo 2007, pp. 47-48; Caputo 1999, p. 186).

Différance, then, correlates with "undecidability" and with Derrida's provocative profession that one must accept various "undecidables," that is, authentic ideas that cannot be deconstructed. Undecidability refers to the legitimate agnosticism that characterizes the process of making genuine decisions. It does not function as a synonym for "indecision" as the tension of having to deliberate between two or more alternatives. On the contrary, and ironically, it actually refers to the necessity of having to decide, the inescapability of taking the leap and choosing without benefit of the security of explicit knowledge. In other words, undecidability means that one can never program the future and predict it with some pre-visionary algorithm; instead, a true decision always traffics with the "to come," the "impossible" that cannot be determined beforehand. One might say, therefore, that undecidability concerns a type of volitional "hope," an anticipation of that which may come, but which may not.

The inherent mystery of deciding conjoins with the idea of the undecidables, since the latter also empower the dynamic of the "to come," or what may also be termed the "messianic." For example, justice, faith, the gift, and democracy are but a few of the ideas that cannot be deconstructed, according 
to Derrida and Caputo. Every manifestation of these ideas in any present fails to instantiate the purity of these notions, s'il y en $a$, "if there is such a thing." Accordingly, these notions remain always "to come," their final expressions deferred until some later time. One might say that they inhere in the messianic spirit that constantly attracts, lures, and calls individuals forward into a potentially transformative reality. In doing so, these messianic "impossibles,"-democracy to come or justice to come or faith to come-disrupt and interrogate every present, "disturbing and interrupting it, haunting and spooking it, soliciting and destabilizing it" (Caputo 2016, p. 57). Yet, the destabilization of the present may well lead to a stabilizing hope, an encouraging expectation of something new, something redemptive, or something therapeutic that is always "to come." Of course, as Caputo honestly notes, that which is "to come" may well be a disaster, something destructive instead of delightful (Caputo 1997a, p. 156; Caputo and Vattimo 2007, p. 48; Caputo 2006, p. 5). Still, human beings routinely hope against hope that what they anticipate coming in the future will, indeed, be edifying or consoling.

Caputo confesses that the passion for the impossible, the hope against hope for that which is "to come" in the uncertainty of an unpredictable future, in the messianic mystery that never attains full disclosure, may also be articulated as a passion for God. "God" is another name for the "impossible" that draws us into the future by calling into question our every present. "God" names "everything we hope for in the future, the name of the one who is coming, or coming again, to save us, to establish a reign of messianic peace" (Caputo 2006, p. 89). Caputo does not know what he loves when he loves his God, thereby affirming an apophatic skepticism that requires the response of faith, which would be the proper response to a "God" who is the "nothing to know"; however, he believes that "God" signifies the dynamic openness that we must always maintain for that which is "to come," although such openness appears at times to be madness (Caputo 2007, p. 84; Caputo 1997b, p. 228; Caputo 2016, p. 4). Nevertheless, this is an example of divine madness that stokes the fires of anticipation and affirms the possibility of a no to the nothing that so often seems to predominate. To be sure, Caputo insists that when the nothing bears down upon us and leaves us with the sense that all hope is gone and that irreparable loss cannot be repudiated, precisely in that specific moment of apparent despair, hope comes to its purest expression, s'il y en a. "God," therefore, names our refusal to surrender to any Stoic passivity that merely consents to reality. It names our miraculous tenacity in the face of adversity, a tenacity that ennobles individuals with a religious fervor that contemplates the messianic future always "to come" and empowers a love of "God" that motivates transformative actions in the present in anticipation of keeping hope alive. One could go so far as to allege that, in Caputo's radical theology, the weak force of anticipation is itself the spirit of "God" exposed.

Of course, one could interpret the Spirit of "God" as the stimulating momentum of anticipation in a number of different ways. One of which, an alternative reading that tracks Caputo's at several points, comes from Richard Kearney and his notion of an anatheistic God. Of course, Kearney's the-ology cannot adequately be classified as a deconstructive approach. He wishes to maintain more of a "theological realism," if for no other reason than to ensure the possibility of differentiating between a creative messiah and a catastrophic monster (See (Kearney 2002)). Kearney does, however, wish to find an alternative to the traditional distinction between theism and atheism and determines that by using the preposition "ana," he may establish such a "third way." "Ana" means "again" or "after" and carries the connotations of "retrieval," "reiterating," or "repeating." Anatheism, therefore, indicates a reiteration of God after God, a returning to God subsequent to a moving through various images of God, which suggests "an unrealized potentiality or promise" in God Godself that remains to be actualized in an unpredictable future (Kearney 2016, p. 22). Anatheism discloses a "hankering after 'something,'" a "spiritual quest" for something more, "something radically Other, uncanny, transcendent, impossible for us to imagine" (Kearney 2016, pp. 33-34, 36).

Unquestionably, Kearney affirms the mystery and non-knowability of the God after God for whom we yearn and after whom we quest. This quest, a version of Augustine's cor inquietum, (Kearney 2001, pp. 62-63) depends upon a "negative capability" that basically paraphrases our idea 
of the nothing to know (Kearney 2016, p. 26). We anticipate, therefore, a God "to come," a God much like Godot, for whom we wait and wait, without knowing for certain who that God is or if that God will, indeed, come (Kearney 2015, Loc. 4813-17). For Kearney, "God" is not only the name for the anticipatory compulsion that drives our hope for a messianic future, but also names the unknowable object of our hope, the nothing to know that may be what is to come as the promise of transformation (Kearney 2015, Loc. 4760-70).

God becomes the object of our hope primarily because God has an "essential" futurity. God cannot be reduced to the atemporality of an Eternal Now but must be understood as harboring a potentiality-to-be that allows for divine mutability. Kearney states quite distinctly that "God neither is nor is not but may be" (Kearney 2001, p. 1); that is, God as the God of promise is always the God "to come," the messianic God of possibility who comes to be "what he [sic] is not yet for us" (Kearney 2001, pp. 4, 30,38). This results in a God who may be, maybe(!), in a certain divine perhaps, perhaps(!). The God who may be can never be exhaustively known or defined within the restrictive categories of human conceptuality. There lingers, consequently, an apophatic uncertainty that leads to an ineffability demanding the necessity of imaginative language, the constant use of metaphors and symbols in order to talk about a God who cannot be talked about for several reasons, one of which is that God maintains an open possibility as to who God will be eschatologically (Kearney 2001, pp. 47, 101). Indeed, Kearney insists that as we respond to the summons of the God "to come," we help God to become God by "opening ourselves to the 'loving possible' by acting each moment to make the impossible that bit more possible" (Kearney 2001, p. 111). The God who may be, therefore, is the nothing to know, the anticipation of which empowers our hope-filled no to nothing by drawing us into a future of meaning that preserves the radical transcendence of God as the (im)possible deity who perpetually promises to be beyond any of our particular expectations.

\section{An Insistent Summons from Beyond}

A cursory reading of Caputo's radical theology might lead to the opinion that he rejects tout court any residual talk about transcendence, given that he so strongly critiques traditional metaphysical theism with its arguments and conclusions about the existence and superior essence of an entitative deity (Caputo 2013, p. 101). One might adduce as evidence for an explicit Caputoan repudiation of transcendence an overt disavowal of the concept in the context of a discussion of Maurice Blanchot's book, Le Pas au-delà. The French allows a double reading of that title; it can be translated as "the step beyond" or as the "no beyond." The English translator of the text chooses to inculcate both meanings and translates it The Step Not Beyond. Obviously, the idea of "beyond" raises the notion of transcendence, since the word etymologically means "to climb across or beyond." To reject the possibility of a stepping forward, pas au-delà, would be simultaneously to dismiss the possibility of any sort of transcendence. Caputo suggests that one could insolently express it as "Transcendence-Not!" The problem with presenting that evidence, however, is that it depends on a total misreading of Caputo's text. The translation of the title does not express his perspective on the concept; as a matter of fact, in the broader context, he attempts to salvage transcendence through an extended discussion of Jesus of Nazareth and goes so far as to identify the "step/not beyond" as "a splendid image of what theology calls the via negativa," which is, naturally, an esteemed linguistic approach to talking about God (Caputo 2007, p. 44).

Actually, Caputo's constant attention to the narratives about and the teachings of Jesus concedes a genuine intent to conserve the language of transcendence, a concept that he confirms not wanting to renounce but to redescribe (Caputo 2013, p. 172). He translates the miracle stories involving Jesus as poetic commentaries on the traces or echoes of an "absconded transcendence" (Caputo 2000, p. 218), a demythologizing of magical accounts into a creative fiction about the transformative dynamic that draws people outward toward fresh possibilities and impossible events that may be "to come" in some absolute future that never closes (Caputo 2001, p. 80). In some respects, his "absconded transcendence" glosses Bonhoeffer's notion of "etsi deus non daretur," in which God intervenes in 
our existence precisely by withdrawing and, apparently, forsaking us, leaving us in the immanence of having to surrender to the power of divine powerlessness, to confessing that what appears to be weakness in the eyes of the world in fact signals the "presence" of God's transcending mercy and love (Bonhoeffer 1972). Caputo likewise emphasizes that "God" must name a weak force that con-founds the strong and confuses the wise through an immanent transcendence of siding with the no-bodies and nothings of the world (Caputo 2000, p. 218). Yet, such a theopassional redescription of transcendence should not be surprising given that Caputo attests to the "essential" transcendent movement that defines deconstruction, a movement that focuses on the unprogrammable and excessive attraction of the messianic. He claims that deconstruction is "a passion for trespassing the horizons of possibility," in other words, a passion for the impossible (Caputo 1997b, p. xix). But this reprises the determining role of anticipation and how it collaborates with transcendence through the extravagance of the "to come," the messianic l'avenir (Caputo 1997a, p. 133).

Naturally, one must never confuse Caputo's perspectives on transcendence with any "Platonic" notion of an epekeina tes ousias. For him, there is no hyperousiological, hyper-Being that mystically surpasses this reality and personifies the omni characteristics that result in a divine being who exercises superior knowledge, power, and will in order to meddle magically in this world for the express purpose of manipulating nature or bestowing exclusionary knowledge on some elite person or privileged community (Caputo 2006, p. 37). Caputo rejects any two-world explanation of transcendence, whereby a supernatural causa sui, or ipsum esse subsistens, or totaliter aliter magically appears to save the day like some divine Mighty Mouse. Caputo considers such a view of God's transcendence to be insulting and demeaning, insinuating that God gets divine kicks from magic tricks and displays favoritism by choosing some and not others, responding to some and not others, or answering some prayers and not others. He admits that one cannot conclusively disprove the strong theology of classical theism; however, he believes that such an understanding of transcendence simply appears more and more unlikely, enhancing a growing sense of incredulity toward a metaphysical view of an entitative deity (Caputo 2013, p. 112). This type of God is not apophatically a nothing to know, but is, literally a "nothing" that cannot be known.

Caputo replaces the notion of God as a divine subject with the idea of "God" as naming a divine summons. He states that were some long-bearded, long-robed pious ecclesiastical prelate to demand a profession of faith in divine transcendence, he would have to testify that the preeminence of "God" would be that of a call or an address. He bears witness to the reality of a call from on high that "lays us low," an event harbored in the name of "God" that invokes our ethical response to the needs of the other, that obligates us to discover and create meaning and purpose through acts of forgiveness, giving, hospitality, and justice. This call is a weak invitation to disrupt and contradict the coercive and arrogant powers that oppress and violate the nobodies in society (Caputo 2006, p. 44). It is a call that comes from a "God" who settles into the mundane and ordinary structures of existence. It indicates that "God's" transcendence is "not that of a fist that smashes, but of a Spirit who breathes, who inspires, and whose gentle breath urges us on" (Caputo 2006, p. 38). Caputo's theopoetics of such a "God," his "anarcho-prophetico-deconstructionist" theology of the weakness of God, results in his replacing the concept "transcendence" with that of "in-scendence" or "insistence." "God" does not exist; "God" insists (Caputo 2006, p. 45). "God is" must be replaced with "God calls," with the divine call being understood as an insistent summons to engage in the moral manifestation of the divine kingdom through acts of mercy and grace. Only in those exercises does one find the meaning and fullness of life that inoculate against the contagion of nihilism. But this means that transcendence cannot be the disjunctive of immanence. It can only be appropriated within the world, as another "worlding of the world" through which what one anticipates and hopes for as redemptive must be discovered or invented in the world itself and not by some magical process by which one can escape the world (Caputo 2013, p. 51).

Interestingly enough, one could accept Caputo's notion of the insistence of God without necessarily using it to supplant the concept of existence. One could actually argue for the "existence" 
of a God of transcendence by adopting what I would call a "transfictional theism," one formulated on a minimalist ontology that allows for God to be considered as an example of what Amie Thomasson calls an "artifactual theory of fiction" (Thomasson 2003, pp. 139-40). Thomasson insists that fiction should not be relegated to the inferior level of language as non-referential or merely emotive. Instead, she attests to the possibility that one may "take some straightforward statements about fictional characters to be true and argue that [one] should claim that fictional objects exist" (Thomasson 1999, p. 107). In other words, fictional characters need not be dismissed as non-existing, non-empirical mental concepts but can be recognized as mental intentions that come to expression in the objectivity of texts, readers, and authors (Thomasson 1999, p. xi). As long as there are texts and readers of those texts whereby fictional characters maintain a certain identity and continuity, one should speak of them as in some way "existing." She explains that "the textual foundation of the character serves as the means whereby a quasi-indexical reference to the character can be made," specifically by a competent reader (Thomasson 1999, p. 47).

Thomasson compares fictional characters to other cultural artifacts that cannot be fully subordinated under either the category of materialism or the category of conceptualism. Such characters are analogous to churches or flags, both of which exist not only as physical empirical realities but also as dependent upon the intentionality and attitudes of individuals who imbue these physical realities with a specific symbolic efficacy (Thomasson 2005, pp. 148-49). Of course, Thomasson recognizes that fictional characters are not fully equivalent to churches and flags as concrete artifacts, but must be interpreted as "abstract artifacts," because they do not genuinely have a "spatio-temporal location" (Thomasson 1999, p. 41). Yet, she insists that they cannot be considered as Platonic ideals either, since they do connect with empirical reality by virtue of the fact that they have been created by a discrete author and are contingent upon the continued real existence of texts and readers. As such, however, they do, indeed, "exist" in the actual world, not in some theoretically possible world, precisely because their existence depends upon the concrete existence of authors, texts, and readers (Thomasson 1999). Furthermore, she insists in her minimal ontology that fictional characters have "some real metaphysical identity...apart from their individuation for consciousness" expressly because their identities transcend "any finite set of contents" (Thomasson 1999, p. 84). In other words, a certain objectivity of identity always exceeds any singular reader's interpretations of the character, which implies for Thomasson that a fictional character can truly cease to exist were the textual foundations for its existence to be destroyed or lost. Fictional characters always exist "according to the story" (Thomasson 1999, p. 107). As long as the story survives, so, too, do its dramatis personae.

Although Thomasson does not apply her artifactual theory of abstract entities to the character of God, there is no compelling reason why that theory cannot apply theologically, given that God "exists" as a character in multiple texts or oral traditions that define the world's religions. Consequently, although one may reject the reality of God as a singular being that transcends the space-time universe, one need not reject that God has a fictional reality, with certain perdurable traits, that functions as the guarantor of meaning and possibility in various literary narratives. In a way, such a transfictional theism connects with Caputo's recent emphasis on Hegel's idea of Vorstellungen. He defines a Vorstellung as "the way truth takes place in a figurative or narratival, mythic or symbolic space" (Caputo 2013, p. 90). Using the Vorstellung of a fictional God, therefore, allows one to create stories about purpose and redemption, about restoration and comfort, and about what Wallace Stevens calls "a blessed rage for order" that portends a check on, or an obstacle to, nihilism (Stevens 1982a, p. 130). God can "exist" as an existentially efficacious "reality" that literally transforms individuals and cultures through the power of a representation of something beyond the quotidian. Such a fictional theological expression of transcendence may well be the "final belief" that grants a foundation upon which to speak the no to nothing. As Stevens theorizes, the "final belief is to believe in a fiction, which, you/know to be a fiction, there being nothing else" (Stevens 1990, p. 189).

To be a faithful Caputoan, one must most assuredly leave open various types of Vorstellungen that can function as embodiments of transcendence. For example, according to Caputo's theopoetics of 
the weak "God," transcendence may well be found in diverse areas of human existence, for example, in "Eros or art [emphasis added], in politics or everyday life" (Caputo 2013, p. 52). In the area of art, I contend that one can easily make a case that the Abstract Expressionism of Mark Rothko, especially in his classical post 1949 canvases, supplies a provocative example of the interface between the no to nothing and the nothing to know as they relate to the meaningfulness of transcendence. Rothko's work has been described "as transcendental, tragic, mystical, violent, or serene; as representative of the void; as opening onto the sublime; as exhilaratingly intellectual; or as profoundly spiritual" (Phillips 2005, p. 1). One can concur with all of these descriptions and argue that they apply precisely because of an inherent interest in transcendence that permeates Rothko's paintings. Julia Davis would certainly assent to that sentiment when she acknowledges that "transcendent" is "one of the most used adjectives in describing Rothko's art" (Davis 2011, p. 21). Through the "push and pull" of floating rectangles that never appear to be static and the vibrating interplay among colors that complement and collide, his canvases intimate that something mysterious strives to reveal itself, something almost mystical that never quite comes to clarity. What initially appear to be floating blocks of solid colors transform constantly into multi-dimensional layers the longer one looks at the paintings. That temporal process of looking instantiates an experience of revelation, the disclosing of nuances that oscillate between the recondite and the recognizable, as if something other struggles toward transparency. Brian O'Doherty explains this kinetic contemplation of Rothko's works by claiming that the "'something else' his art contains or elicits is too positive to be a void, too negative to be a substance. We can call it mystery or enigma" (O'Doherty 2015, p. 125).

The enigmatic character of Rothko's paintings exhibits a transcendence that allows for a religious hermeneutic. He, himself, confirms the spiritual intent behind his abstractions when he writes that he desires spectators to experience his canvases in such a manner that they have the same religious experience that he had when painting them (Rothko 2006, pp. 119-20). In other words, he considers his work to be communicative and evocative of a genuine human experience with what, in that experience, signals a certain mystery "beyond" the surface level. Not surprisingly, therefore, he confesses that he never wants to minimize the material reality of existence. He does, nonetheless, admit that his art is "mythical" in that it seeks to correlate the substance of the real with what lies beyond the real, that is, to achieve a form of immanent transcendence (Rothko 2006, p. 46). Consequently, the spectator may well be confronted with "hidden but immanent truths of the universe" that might "offer immediate access to the divine" (Elderfield 2005, p. 101). Perhaps one could borrow a phrase from Robert Rosenblum and call Rothko's intimations of the divine a form of "paint-theism" (Rosenblum 1961)!

The emphasis upon transcendence and the spiritual comes to unique expression in the Seagram Murals at the Tate Modern and in the abstract altar pieces displayed in the Rothko Chapel. The former canvases all embody shapes reminiscent of doors or portals through which one may journey in and out of the paintings. Such transitional forms strongly suggest the potentiality of transcendence and the symbolism of "the way" as a spiritual or religious quest. These paintings invite viewers to take a step beyond, move into a space of transformation, or make a pilgrimage into alternative perspectives on existence. Conversely, the apertures may lead to nowhere or denote closed accesses. Either way, a mystery remains (Davis 2011, p. 81). Likewise, the Rothko Chapel murals with their ersatz formless voids of empty nothingness transform themselves into a multitude of chromas and configurations that motivate visual metamorphoses, arousing in the spectator an almost spiritual ascesis and a devotional discernment of something more within or beyond the banality of everydayness (Davis 2011, pp. 70-72). As Rothko's son, Christopher, summarizes them, the "chapel murals exist at the intersection of everything and nothing. They are silence and a full-voiced shout...They speak simultaneously of the never was in the ever shall be" (Rothko 2015, p. 120).

Julia Davis would condense the aesthetic transcendence in Rothko's works to the efficacy of "clouds" as a symbol for Rothko's approach. She specifies that he actually uses the word in certain titles, for example, Blue Cloud, 1956 and Light Cloud, Dark Cloud, 1957; however, she also applies the word to the broader apophatic qualities of his classical period. She connects Rothko to the 
famous mystical text, The Cloud of Unknowing, which overtly addresses the proper way of knowing God through the discipline of non-knowing. Rothko's "clouds" become "abstract equivalents for the aura surrounding certain divine entities," almost "halos" that witness to the "presence" of the sacred (Davis 2011, pp. 18-19). Such artistic halos conjure up the possibility of the numinous while protecting the sanctity of the vague (Davis 2011, p. 59). Yet, the sanctity of the vague in many ways defines the substance of the mystical, what Catherine Keller terms the "persistent attunement to the mystery" (Keller 2008, Loc. 604-7), what in this essay goes under the rubric "the nothing to know." Such mysticism demands faith as the pertinent response, since Keller considers faith to be a stepping with trust into unpredictable future possibilities (Keller 2008, Loc. 153-55). In Cloud of the Impossible, a text aptly named for associating with Rothko considering Davis's vaporous symbolism of his apophatic artistry, Keller correlates this fiduciary no to nothing with "negative capability," the very Keatsian term that Kearney also uses to accentuate the inevitability of "uncertainties, mysteries, [and] doubts, without any irritable reaching after fact and reason" (Keller 2015, p. 14). "Negative capability" indicates that we strive not to attain complete knowledge and Cartesian certainty but to achieve a productive "incomplete ignorance" (Keller 2015, p. 11). Keller encompasses all of this in the brief phrase "apophatic entanglement," by which she means the relationality of all possibilities, the constant journeying toward the transcendent "to come" that requires a perdurable repetition forward (Keller 2015, p. 16). Yet, this is precisely what Rothko's art encourages, since one soon realizes that his paintings compel multiple viewings in order to encounter the subtleties of his expressions, but always with the concession that their meanings can never be exhausted. The apophatic entanglement among artist, canvas, and spectator, therefore, habitually establishes a belief in a putative transcendence that transcendentally ratifies a no to nothing while leaving open the ambiguity of a nothing to know.

\section{The "Nihilism of Grace" as the End of "Why"}

The "worlding of the world" that defines Caputo's immanent transcendence naturally extends into the area of his "interim eschatology" (Caputo 2013, p. 256). He rejects any traditional view of eschatology as the replacement of this space-time historical existence with another eternal and spiritual reality, what he terms the "Why in the Sky of classical eschatology" (Caputo 2015, p. 159). If there is any eschatological telos that offers meaning to existence, it must come within the secular and sublunary processes of this reality. Interim eschatology recognizes along with Fogelberg that any answers to life's questions must be found in the dreams dreamed along the way during life itself, since there is only life and death, this world and no other. In this interim existence, we learn that the universe does not need us; it is, as Albert Camus claims, oblivious to our actuality to the point that the relationship between an impersonal universe of cosmic processes and the personal yearning for purpose that characterizes the deepest longings of humanity results in an absurdity that cannot be circumvented through some facile application of either logic or faith (Camus 1955, pp. 3-63). As Caputo states, "the universe does not need us"; nevertheless, he continues, "but God, the name (of) 'God,' does need us" (Caputo 2013, p. 256). We usher in a realized eschatological presence of "God" whenever we respond to the divine call and submit to the lure of "God" as it draws us into an ethical obligation toward the other, an obligation that motivates us to wipe away tears, to instantiate justice, and to seek to conquer violence (Caputo 2015, p. 116). Yet, this ethico-political incarnation of "God" is the inauguration of the eschatological Kingdom (Caputo 1997b, p. 168; Caputo 2006, p. 52); it is the embodiment of the transcendent love of "God" (Caputo 2001, pp. 140-41); and it is the "insistence of a chance for existence, in the grace of a chance for life, for more life, perhaps. God does indeed play dice, a game of chance with grace" (Caputo 2013, p. 237).

This eschatology of grace does not grant Caputo special knowledge about the foundations for a resolution or redemption of human existence. It remains a theology of the "perhaps," an anarchical denouement that never ceases, even a "sacred anarchy" that promotes establishing both "God" and the divine Kingdom through acts of mercy that portend the messianic coming of a future that cannot be foreknown. This is the nothing to know, the nothing that cannot ever be known in any conclusive 
sense. It is the "to come" as a contingent, aleatoric potentiality for something, a something that can be guessed but never guaranteed. Caputo claims that "we are forged from fragile stuff" that leaves us vulnerable to an eschaton of transformation or an eschaton of tragedy (Caputo 2013, p. 261). But that is a sentiment reminiscent of Prospero, who reminds us that "we are such stuff/As dreams are made on, and our little life/Is rounded with a sleep" (Shakespeare 1989). Fogelberg's dreams once again! Still, they are dreams that signal no other reality, that envision no powerful intervention from an omnipotent deity who can swoop down, end history, and make everything right again. They remain eschatological dreams of the "perhaps," of the nothing to know, of (the) nothing that offers any escape from the loss and uncertainty, the fear and anguish, or the hoping against hope that leads us to take the next step (not) beyond (le pas au-delá).

Nevertheless, to be honest, there seems to be something rather disappointing in Caputo's eschatology, something that fails to offer any solace or promise that meaning and purpose might one day be discovered or created. Are we not simply stuck with more of the same with no assurance that good can and will prevail? In other words, are we not left with anticipating merely the immanent transcendence of an eschatological repetition of an enervating monotony? And then we die! That does not intimate any valid "no" to the nothingness that envelops us. Caputo is certainly not insensitive to that conclusion. He acknowledges that we cannot evade the threat of nihilism. If there is only this reality of matter and energy, then we must admit that the final end is a "cosmic nihilism," that, according to some of the best cosmological physics we have, the universe will continue to expand until matter itself disintegrates into the cold nothingness of a deep, frozen vacuum. "This is the way the world ends/Not with a bang but a whimper," writes the pre-Christian Eliot (Eliot 1963b). Such a nihilism can only end in hopelessness, the death of any valid expectation that the future may hold value. Nihilism, therefore, means that one cannot ever truly say a "no" to nothing, unless it is simply the resigned sigh of an "Oh, no" that accepts that only "the nothing" triumphs (Caputo 2015, pp. 8-9). Caputo rightly inquires as to whether there is "any hope for hope" in the melancholy of this desolation. He asks, "If we square off with nihilism, if we face up to the facelessness of the inhuman, of implacable death-divested of the God of Omnipotence, who makes our enemies our footstool, disarmed of the Lord of Hosts and of the gods of technology...what now" (Caputo 2015, p. 157)?

Caputo answers his own question positively, hopefully, with an energized anticipation in the immanence of transcendence; that is to say, he responds with a definite no to nothing that precipitates redemptively out of his nothing to know. He insists that his "theopoetics of "perhaps'" leads inevitably to a "nihilism of grace" (Caputo 2013, pp. 22-23). He dictates that we should neither bind nihilism within some ontotheological system of thought nor let it run loose by acquiescing to thermal equilibrium and the Big Freeze. Instead, we should willingly embrace the transience of existence, rec-ognize that the value of life lies strictly in its finitude, in the inevitability of the ending of all things. Existence should be treasured simply because it is not eternal. It will be lost eventually; therefore, we should "hold things dear by holding them fast, and we hold them fast because we know that we can-not hold on to them forever" (Caputo 2013, p. 227). This is what he means by the "nihilism of grace," the fact that we have been given life for but a short while.

Fortunately, Caputo does not have to attenuate his commitment to contemporary science for the sake of arguing the validity of his "nihilism of grace." For example, Stuart Kauffman, a theoretical biologist and Emeritus Professor of Biochemistry at the University of Pennsylvania, laments over the reductionism of what he calls a "hard-headed realism." He claims that "rampant scientism" has de-nuded the world of mystery and left it disenchanted (Kauffman 2016, Loc. 895-97). This leads to the threat of a nihilism that Kauffman thinks has been expressed quite succinctly by the Nobel Laureate physicist Stephen Weinberg: "The more we know of the universe, the more meaningless it appears" (Kauffman 2008, Loc. 108). Yet, Kauffman rejects the necessity of this conclusion, primarily because he identifies a creative impulse in the universe predicated upon its complexity and its inter-relationality. He interprets a "radically emergent" dynamic at work in the universe that produces an open future that cannot be pre-stated or predicted by virtue of the fact that each New Actual produces new 
Adjacent Possibles; that is, in a manner reminiscent of the "butterfly effect," Kauffman contends that as the universe evolves, each new structure opens up the potential for subsequent structures that could not have been totally foreseen according to any absolute physical laws (Kauffman 2016, Loc. 697-98). Every actuality of a possibility, therefore, inaugurates new possibilities to be actualized. In this "autopoetic system," the future remains functionally unknowable, not merely because of the limitations of human rationality but, more ontologically, because reality itself transcends informed predictions (Kauffman 2016, Loc. 1450-51; Kauffman 2008, Loc. 252). One can never totally predict what contingencies might develop in the future; consequently, one might paraphrase Kauffman's position as an acceptance of the biological "to come," as a scientific messianic anticipation of an unprogrammable future that maintains a certain eschatological openness advancing the potentiality of surprise and transformation.

Roberto Unger and Lee Smolin also agree with Kauffman's "autopoetic system," referring to it as a "temporal naturalism" (Unger and Smolin 2015, p. xvii). They claim that if time is real, then the universe has a history, which confirms that even the laws of nature are liable to mutability. One should never be guilty of the "fallacy of universal anachronism" and assume that contemporary natural laws have always been in effect throughout the early periods of the universe (Unger and Smolin 2015, pp. xvi, 19). In another work, Smolin explains that the future cannot be absolutely determined on the basis of any current theories, given that conditions may well evolve in the future and, therefore, constitute the possibility of surprise. The temporality of the universe, as a result, warrants that novelty can develop and that creativity and imagination have a significant effect on existence, thereby overcoming the necessity of nihilism by leaving open the meaning of a new configuration of existence (Smolin 2014, p. 16).

Kauffman infers from the "autopoetic system" or "temporal naturalism" inherent in the universe that one can transcribe the scientific tolerance of genuine novelty and creativity into a theological idiom. He argues that the creative impulse that permeates reality can be named "God" (Kauffman 2008, Loc. 140). Of course, he does not interpret God in a traditional metaphysical sense, opting, in-stead, to follow Caputo and reject the language of a strong theology in which God is an omnipotent being intervening in the processes of nature. Kauffman admits that we have created God ourselves but have done so in order to have a powerful symbol for the prolific productivity in the universe itself that allows for the future to be different from the past and for meaning to be a viable legacy of the ongoing universal processes (Kauffman 2008, Loc. 167). For him, "God, a fully natural God, is the very creativity in the universe," and such a theology "can be a shared religious and spiritual space for us all" (Kauffman 2008, Loc. 263).

I think that Caputo would embrace, with alacrity, such a scientific perspective on the autotelic nature of existence. He would conclude that the contingencies and coincidences of existence communicated through Kauffman's, Unger's, and Smolin's theories have been given for no reason, just as is any pure gift. A gift comes because it comes, without any sense of duty or exchange or response (Caputo 2015, pp. 171-72). But what exactly does that mean? It means that the "nihilism of grace" should be a "joyous and gratuitous nihilism," one that celebrates life for no reason other than the fact that life is (Caputo 2013, p. 240). Life is for nothing; it has no purpose beyond itself; it is autotelic. But this idea returns Caputo to his early roots in mystical thought by once again reprising the magnitude of the ohne warum, the "without why" professed so beautifully by Angelus Silesius (Caputo 1986, pp. 97-100). It is the mysticism of the rose, the rose that blooms without why, that blooms because it blooms. Life is that rose. We live because we live; we live in order to live. We anticipate more life in the future, more life that transcends any present living of life, and we anticipate the life "to come" as a realized eschatology, as the "immediacy of the moment, of eating and drinking, of making friends and making love, of giving and forgiving, of joy and sorrow" (Caputo 2013, p. 238). But in these moments, we must also respond to the call of "God" to love one another, to respond to the other with mercy, grace, and forgiveness. We are entrusted with making God's kingdom come on earth, with incarnating the God of love through acts of love and compassion. Will doing so make a difference? Will the future 
be better? Is there any chance of the realization of what we hope for in the future? Perhaps. Perhaps there is a God who will make some things right again. Perhaps not. All of that is part of the nothing to know. Still, in our uncertainty and non-knowing, we must continue to live, to hope, to anticipate, and in the nihilism of grace to voice our no to nothing.

The voicing of the "no" to nothing, regardless of whether it occurs in concert with the help of God or not, must exemplify the immanent transcendence of a "realizing" eschatology. Ray Hart grasps this truth as he struggles to comprehend the significance of the "nothing." He diagnoses the challenge of thinking to be whether "the nihil [can] be given its due without issuing in nihilism" (Hart 2016, p. 25). In other words, can the nihil "be given its due without resulting in an exhaustive nihilism, construed as utter indifference to matters of meaning and value" (Hart 2016, p. 30). Hart answers this question affirmatively by noting that human beings must negotiate between two "nothings," the "nothing" from which we come, as in some creatio ex nihilo, and the "nothing" toward which we journey, our ownmost possibility of impossibility, i.e., death (Hart 2016, p. 238). Hart contends that the interim period between the two "nothings" should not be spent in some nostalgia for the first "not," for the recapitulation of some earlier glory days or Edenic existence. Instead, we should dedicate ourselves to moving resolutely into the future in order to establish the reality of a new and more creative reality. This "ontic-meontic" emergence from nothing toward nothing should produce a redemptive transformation of existence as individuals write a new text, produce a meaningful and purposeful narrative of what life can be (Hart 2016, p. 242). This amounts to Hart holding fast to an eschatology that instantiates a creatio continua, which, for him, signals a redemptive God who calls us to be conformed ad imaginem Verbi, a decidedly Christian reading of the eschaton (Hart 2016, p. 96). Redemption as a check on the deleterious effects of a genuine nihilism depends upon an unfinished creation, one that remains exposed to difference and alterity, to acts of mercy and grace, and to any attempt to fulfill the autotelic essence of life itself.

\section{The Sacramental No to Nothing: Ex Opere Operato}

Jacques Derrida and Paul Ricoeur died within seven months of each other, the former in October 2004 and the latter in May 2005. Interestingly enough, in the months just prior to their passing, both men reflected on their mortality, leaving as part of their bibliographical legacies two memento mori that reveal an interesting continuity between their individual conclusions about existential meaning and the proper perspective to take on finitude. The titles of their reflections expose their biases: Learn-ing to Live Finally for Derrida and Living Up to Death for Ricoeur (Derrida 2007; Ricoeur 2009). Both men emphasize the centrality of the concept of "living," to the point that even in the face of dying, living predominates. In various texts, both authors explicitly dismiss Heidegger's popular existential, Sein-zum-Tode, "being toward death," choosing, instead, to identify with a more existentially elevating characteristic for Dasein. Ricoeur prefers to replace it with "being until death," which may be interpreted as another version of his idea that human beings maintain a certain "primary affirmation" that refuses to succumb to any despair concerning the importance of existence (Ricoeur 1998, pp. 145-46, 156; Ricoeur 2009, p. 12; Ricoeur 1965, pp. 305-28; Ricoeur 1980, pp. 149-53). Derrida substitutes "surviving to death," which advocates "an unconditional affirmation of life" and an openness to the futurity of existence (Derrida 2007, pp. 51-52). This position directly tracks Derrida's constant insistence that deconstruction depends on a positive perspective on existence, a oui, oui, or yes, yes, to life (Derrida 1985, p. 14). Both of these philosophers contribute fascinating synonyms for what in this essay is called "the no to nothing," the repudiation of nihilism that encourages a tenacious anticipation for a transcendence that alleges the eschatological reality of something that can ensure meaning and purpose. Not surprisingly, a broader reading of these two theorists also confirms that what that transcendence might be can never be comprehensively classified. Ricoeur's acceptance of "the secret" and Derrida's embrace of the "messianic" reminds us that we can never escape the nothing to know that exposes us to the aleatoric and the contingent. Consequently, we are left in a Caputoan 
context in which we must live life without a definitive "why," simply embrace the nihilism of grace in order to discover and invent a satisfying raison d'être.

In this essay, I have attempted to investigate the tenacity of primary affirmation and the necessity of repeating the oui, oui to existence by examining only a few of the multiple commentaries on how to hold in tension the no to nothing and the nothing to know, to comply with the inevitability of a systemic non-knowing that does not constrain the resignation to meaninglessness. Each one of the proposals examined in this essay strives to account for a functional affirmation of life while simultaneously acceding to what Jean-Luc Marion would call a "negative certainty." Marion asserts that all knowing is ultimately Cartesian, depending on the realization of a certainty devoid of doubt. Nevertheless, he insists that we can never attain that kind of certainty; as a result, we cannot know as much as we desire to know. We are left with only the possibility of thinking past that unattainable barrier. In his words, we can only achieve a "negative certainty," the certainty that we can never be certain about ultimate questions of existence (Marion 2015, pp. 1-5). Yet, this negative certainty does not disenfranchise our constantly confronting questions about anticipation, transcendence, and eschatology, more specifically, questions about how these concepts connect with the possibility of a God who, although inaccessible, may be theorized to be the guarantor of the validity of engaging these ideas (Marion 2015, p. 51). In other words, one can never evade the fact that all struggles with nihilism and the possibility of optimism evoke the question of God. Ironically, however, this question may well be the unanswerable question about which Marion speculates. He contemplates the question that can never be answered by a finite mind: "insofar as such a question is always being asked and left without an answer, and it survives this absence, does it not give a reality to be thought (cogitabile)? And does it not merit the rank of a negative certainty. For even denegation can be a matter of givenness" (Marion 2015, p. 7).

The above speculation elicits for me the issue of whether there might be, behind all of the narratives of hope and affirmation recounted in this essay, something at work encouraging the continual anticipation of a transcendent value that implies an eschatological purpose, one that, of course, can never be truly known. Whether we translate that affirmation into the idioms of a Caputoan "nihilism of grace," or a Kearnian "anatheistic potentiality," or a Thomassonian "transfictional theism," or a Rothkoan "abstract revelation of mystery," or a Kellerian "cloud of entanglement," or a Kauffmanni-an "autopoetic system," or a Hartian "ad imaginem Verbi," the efficacy of a no to nothing and the nothing to know pragmatically works to instill attitudes of hope, courage, and a celebration of the value of existence. All of these theories then have a certain sacramental dynamic about them, since all of them denote some aspect of grace and the possibility of transformation. The no to nothing, therefore, succeeds ex opere operato, not because any one of the expressions captures the "truth" of the affirmation of life, but because there is at work in all of them something "given," something structurally unknowable that might, perhaps, just maybe, offer the motivation to continue to anticipate something beyond that suggests an end without closure.

Some nothing to know may well be working surreptitiously to empower every anecdote of our ambitions toward redemption, so much so that, regardless of how we may choose to explain that salvific stimulus, all of our explanations work. In other words, perhaps, just perhaps, by the work of the eschatological mystery itself, they work. They work ex opere operato regardless of how they are named, although we can never know how that working works or by what work they work. That negative certainty, I guess, will have to suffice; perhaps we need know nothing other than that. Still, may-be, just maybe, in a plurality of discourses, we can posit a transcendence that endorses hope and enflames the anticipation for a serenity "to come" without why, to bloom as does the autotelic rose. Perhaps, just perhaps, we can pray without ceasing for the mystery of an Eliotian eschatology: "And all shall be well and/All manner of things shall be well/When the tongues of flames are infolded/Into the crowned knot of fire/And the fire and the rose are one" (Eliot 1963a).

Conflicts of Interest: The author declares no conflict of interest. 


\section{References}

Bonhoeffer, Dietrich. 1972. Letters and Papers from Prison, the Enlarged ed. Edited by Eberhard Bethge. New York: Collier Books, pp. 360-61.

Browning, Robert. 1974. Andrea del Sarto. In The Norton Anthology of English Literature, 3rd ed. Edited by M. H. Abrams. New York: W.W. Norton \& Company, vol. 2.

Camus, Albert. 1955. The Myth of Sisyphus and Other Essays. Translated by Justin O'Brien. New York: Vintage International.

Caputo, John D. 1986. The Mystical Element in Heidegger's Thought. New York: Fordham University Press.

Caputo, John D. 1997a. Deconstruction in a Nutshell: A Conversation with Jacques Derrida. New York: Fordham University Press.

Caputo, John D. 1997. The Prayers and Tears of Jacques Derrida: Religion without Religion. Bloomington: Indiana University Press.

Caputo, John D. 1999. Apostles of the Impossible: On God and the Gift in Derrida and Marion. In God, the Gift, and Postmodernism. Edited by John D. Caputo and Michael Scanlon. Bloomington: Indiana University Press.

Caputo, John D. 2000. More Radical Hermeneutics: On Not Knowing Who We Are. Bloomington: Indiana University Press.

Caputo, John D. 2001. On Religion. New York: Routledge.

Caputo, John D. 2006. The Weakness of God: A Theology of the Event. Bloomington: Indiana University Press.

Caputo, John D. 2007. What Would Jesus Do? The Good News of Postmodernism. Grand Rapids: Baker Academic.

Caputo, John D. 2013. The Insistence of God: A Theology of Perhaps. Bloomington: Indiana University Press.

Caputo, John D. 2015. Hoping Against Hope: Confessions of a Postmodern Pilgrim. Minneapolis: Fortress Press.

Caputo, John D. 2016. The Folly of God: A Theology of the Unconditional. Salem: Polebridge Press.

Caputo, John D., and Gianni Vattimo. 2007. After the Death of God. Edited by Jeffrey W. Robbins. New York: Columbia University Press.

Davis, Julia. 2011. Mark Rothko: The Art of Transcendence. Kent: Crescent Moon Publishing.

Derrida, Jacques. 1985. The Ear of the Other: Otobiography, Transference, Translation. Translated by Peggy Kamuf. Lincoln: University of Nebraska Press.

Derrida, Jacques. 2007. Learning to Live Finally: An Interview with Jean Birnbaum. Translated by Pascale-Anne Brault, and Michael Naas. Hoboken: Melville House Publishing.

Elderfield, John. 2005. Transformations. In Seeing Rothko: Issues and Debates. Edited by Glenn Phillips and Thomas Crow. Los Angeles: Getty Research Institute.

Eliot, T. S. 1963. The Four Quartets: Little Gidding. In T. S. Eliot: Collected Poems 1909-1962. New York: Harcourt Brace and Company.

Eliot, T. S. 1963. The Hollow Men. In T. S. Eliot: Collected Poems 1909-1962. New York: Harcourt Brace and Company.

Fogelberg, Dan. 1974. Souvenirs: Part of the Plan. Full Moon/Epic Records, 1 compact disc. Recorded in 1974.

Hart, Ray L. 2016. God Being Nothing: Toward a Theogony. Chicago: The University of Chicago Press.

Kauffman, Stuart A. 2008. Reinventing the Sacred: A New View of Science, Reason, and Religion, kindle ed. New York: Basic Books.

Kauffman, Stuart A. 2016. Humanity in a Creative Universe, kindle ed. New York: Oxford University Press.

Kearney, Richard. 2001. The God Who May Be: A Hermeneutics of Religion. Bloomington: Indiana University Press.

Kearney, Richard. 2002. Strangers, Gods and Monsters: Ideas of Otherness. London: Routledge.

Kearney, Richard. 2015. Derrida and Messianic Theism. In The Trace of God: Derrida and Religion, kindle ed. Edited by Edward Bering and Peter E. Gordon. New York: Fordham University Press.

Kearney, Richard. 2016. God After God: An Anatheist Attempt to Reimagine God. In Reimagining the Sacred: Richard Kearney Debates God. Edited by Richard Kearney and Jens Zimmerman. New York: Columbia University Press.

Kierkegaard, Søren. 1983. Fear and Trembling/Repetition. Edited and translated by Howard V. Hong and Edna H. Hong. Princeton: Princeton University Press.

Keller, Catherine. 2008. On the Mystery: Discerning Divinity in Process, kindle ed. Minneapolis: Fortress Press.

Keller, Catherine. 2015. Cloud of the Impossible: Negative Theology and Planetary Entanglement. New York: Columbia University Press. 
Kermode, Frank. 1967. The Sense of an Ending: Studies in the Theory of Fiction. New York: Oxford University Press. Lord Tennyson, Alfred. 1974. Ulysses. In The Norton Anthology of English Literature, 3rd ed. Edited by M. H. Abrams. New York: W. W. Norton \& Company, vol. 2, p. 843.

Marion, Jean-Luc. 2015. Negative Certainties. Translated by Stephen E. Lewis. Chicago: The University of Chicago Press.

O'Doherty, Brian. 2015. Mark Rothko: The Tragic and the Transcendental. In Mark Rothko: An Essential Reader. Edited by Alison de Lima Greene. Houston: The Museum of Fine Arts Houston.

Phillips, Glenn. 2005. Introduction: Irreconcilable Rothko. In Seeing Rothko: Issues and Debates. Edited by Glenn Phillips and Thomas Crow. Los Angeles: Getty Research Institute.

Rosenblum, Robert. 1961. The Abstract Sublime. ARTnews. Available online: http://www.artnews.com/ 2015/03/27/beyond-the-infinite-robert-rosenblum-on-sublime-contemporary-art-in-1961 (accessed on 11 April 2017).

Ricoeur, Paul. 1965. History and Truth. Translated by Charles A. Kebley. Evanston: Northwestern University Press. Ricoeur, Paul. 1980. Essays on Biblical Interpretation. Edited by Lewis S. Mudge. Philadelphia: Fortress Press.

Ricoeur, Paul. 1998. Critique E Conviction: Conversations with François Azouvi and Marc de Launay. Translated by Kathleen Blamey. New York: Columbia University Press.

Ricoeur, Paul. 2009. Living Up To Death. Translated by David Pellauer. Chicago: The University of Chicago Press. Rothko, Mark. 2006. Writings on Art. Edited by Miguel López-Remiro. New Haven: Yale University Press.

Rothko, Christopher. 2015. Mark Rothko: From the Inside Out. New Haven: Yale University Press.

Scharlemann, Robert. 1989. Inscriptions \& Reflections: Essays in Philosophical Theology. Charlottesville: University of Virginia Press.

Shakespeare, William. 1989. The Tempest. In The Unabridged William Shakespeare. Edited by William George Clark and William Aldis Wright. Philadelphia: Courage Books, Act IV, Sc. 1, Lines 156-58.

Smolin, Lee. 2014. Time Reborn: From the Crisis in Physics to the Future of the Universe. New York: Houghton Mifflin Harcourt Publishing Company.

Stevens, Wallace. 1982. The Idea of Order at Key West. In Wallace Stevens: The Collected Poems. New York: Vintage Books.

Stevens, Wallace. 1982. The Snowman. In Wallace Stevens: The Collected Poems. New York: Vintage Books.

Stevens, Wallace. 1990. Adagia. In Opus Posthumous. Edited by Milton J. Bates. New York: Vintage Books.

Thomasson, Amie L. 1999. Fiction and Metaphysics. Cambridge: Cambridge University Press.

Thomasson, Amie L. 2003. Fictional Characters and Literary Practices. British Journal of Aesthetics 43: 138-57. [CrossRef]

Thomasson, Amie L. 2005. Ingarden and the Ontology of Cultural Objects. In Existence, Culture, and Persons: The Ontology of Roman Ingarden. Edited by Arkadiusz Chrudzimski. Frankfort: Ontos.

Unger, Roberto Mangabeira, and Lee Smolin. 2015. The Singular Universe and the Reality of Time: A Proposal in Natural Philosophy. Cambridge: Cambridge University Press.

(C) 2017 by the author. Licensee MDPI, Basel, Switzerland. This article is an open access article distributed under the terms and conditions of the Creative Commons Attribution (CC BY) license (http://creativecommons.org/licenses/by/4.0/). 